\title{
Mortality of Kalliapseudes schubartii in Unvegetated Soft Bottoms of the Estuarine Region of the Lagoa dos Patos
}

\author{
Duane Barros Fonseca* and Fernando D'Incao \\ Laboratório de Crustáceos Decápodes; Departamento de Oceanografia; FURG; C. P. 474; 96201-900; \\ dbfl@mac.com; Rio Grande - RS - Brasil
}

\begin{abstract}
Studies were carried iut on seasonal mortality by taking samples of Kalliapseudes schubartii (Crustacea: Tanaidacea) for a year in the estuarine region of the Lagoa dos Patos (southern Brazil). Results demonstrated no significant difference in seasonal mortality rates, which suggest that populations of $\underline{K}$. schubartii was heavily preyed on year round and that an assumption of a significantly higher mortality in summer/autumn than in spring/winter might not be held in unvegetated soft bottoms of the estuarine regions of the Lagoa dos Patos.
\end{abstract}

Key words: Tanaidacea, Kalliapseudes schubartii, mortality

\section{INTRODUCTION}

Kalliapseudes schubartii Mañé-Garzón, 1949 (Tanaidacea, Kalliapseudidae) is a tube dwelling organism that inhabits estuarine subtidal soft bottoms along the southeast and southern Brazilian, and Uruguayan coasts (Lana and Guiss, 1991; Leite, 1995; Bemvenuti, 1997; Muniz and Venturini, 2001). This tanaid is both a deposit and filter-feeder that, in turn is prey for several secondary consumers (Bemvenuti, 1997b). In the estuarine region of the 'Lagoa dos Patos' (Patos Lagoon), while individual growth and reproductive parameters of $K$. schubartii have been previously studied (Fonseca and D'Incao, 2003), mortality rates have never been quantified. Regarding mortality rates, it has been hypothesized that $K$. schubartii would be the most preyed on when juveniles of fish and crustaceans use the estuarine region as nursery grounds (Bemvenuti, 1997b).
This study reports findings on seasonal mortality rates of a population of $K$. schubartii in the estuarine region of the Lagoa dos Patos (Rio Grande do Sul State, Southern Brazil).

\section{MATERIAL AND METHODS}

Tanaids were collected from subtidal soft bottoms in the estuarine region of the Lagoa dos Patos $\left(32^{\circ} 01^{\prime} 51^{\prime \prime} \mathrm{S} 52^{\circ} 07^{\prime} 96^{\prime \prime} \mathrm{W}\right)$. The location sampled had shallow waters (depth $<1.5 \mathrm{~m}$ ), without submersed spermatophytes, and the sediment was composed mostly by fine sand (Rosa-Filho and Bemvenuti, 1998). Monthly samples were taken, from July 1996 to June 1997. Sampling was carried out along a $20 \mathrm{~m}$ transect using a stratified design (3 stratum, first at the beginning of the transect, the second at $10 \mathrm{~m}$, and the third at 20 $\mathrm{m})$. Twelve replicates (4 in each strata) were randomly taken with a $10 \mathrm{~cm}$ diameter core $(20 \mathrm{~cm}$ deep). The collected sediment was washed through

\footnotetext{
* Author for correspondence
} 
a $300 \mu \mathrm{m}$ sieve and the retained material was taken to the laboratory where the individuals of $K$. schubartii were sorted from the debris, fixed, preserved (4\% formalin), sexed, and measured. Total length (TL, from the tip of the rostrum on

A

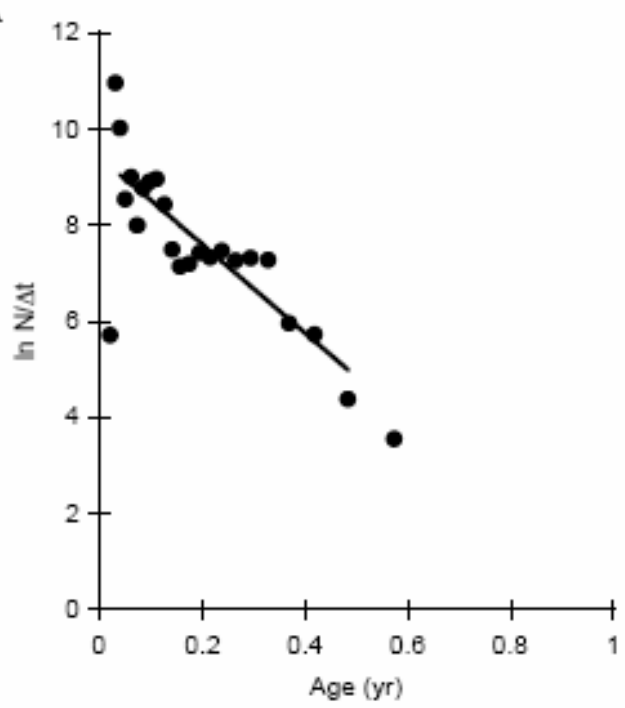

C

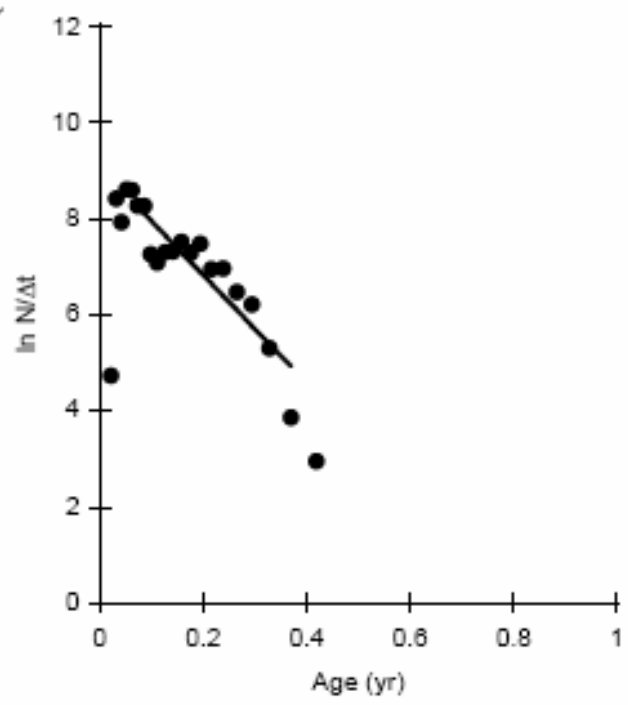

the carapace to the posterior edge of the pleotelson) was measured using an ocular micrometer. Individuals $\leq 2.5 \mathrm{~mm}$ TL were defined as juveniles, provided that none of these animals presented secondary characteristics of males.

B

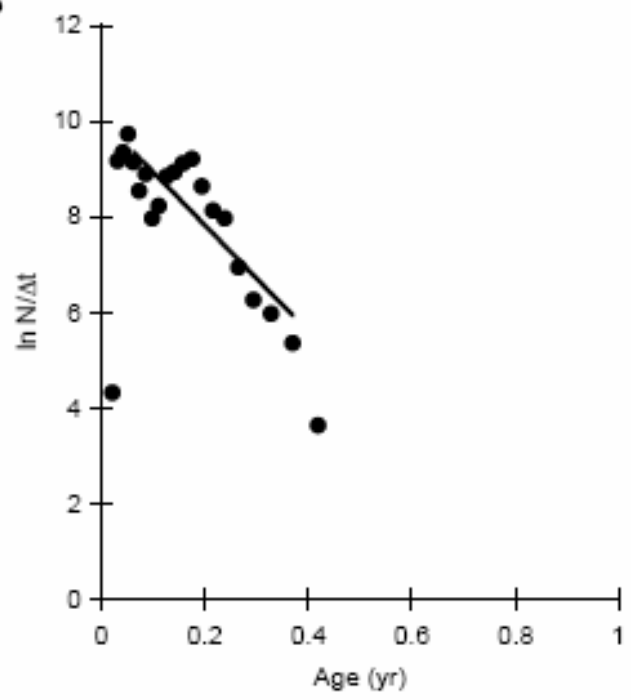

D

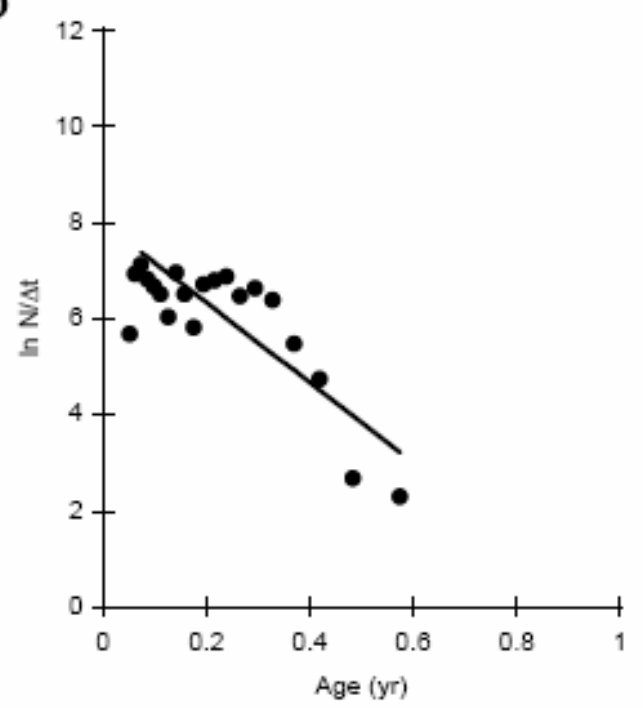

Figure 1 - Seasonal catch curves. (A) spring, $\mathrm{y}=9.43-9.17 \mathrm{x}, \mathrm{N}=20$; (B) summer, $\mathrm{y}=10.06-11.11 \mathrm{x}$, $\mathrm{N}=16$; (C) autumn, $\mathrm{y}=9.04-11.14 \mathrm{x}, \mathrm{N}=16$; (D) winter, $\mathrm{y}=7.98-8.29 \mathrm{x}, \mathrm{N}=17$. N, number of points used to fit the regression line. All regressions were statistically significant at $\alpha=0.05$.

To estimate the mortality rate, age determination was performed indirectly by length-based methods. Parameters of individual growth (von Bertalanffy growth model) estimated for this population (Fonseca and D'Incao, 2003) were utilised to convert length to age (t). Instantaneous rate of total mortality $(\mathrm{Z})$ was estimated by length converted catch curve $-\ln (\mathrm{N} / \Delta \mathrm{t})=\mathrm{a}+\mathrm{bt}$ - where the slope of regression (b) is the estimate of $\mathrm{Z}, \mathrm{N}$ is the number of individuals in a given length class, $\Delta \mathrm{t}$ is the time for the individuals growth through that length class and $t$ is the mean age of 
the individual in that length class (Pauly, 1990). To estimate each regression line, the first point utilised was that immediately to the right of the highest point; the rightmost point was not included. Catch curves were estimated for each season, and they were compared by analysis of covariance.

\section{RESULTS}

A total of 4102 individuals was collected (1799 females, 539 males and 1764 juveniles). Seasonal catch curves are shown in Fig. 1. The instantaneous rate of total mortality was not statistically different among seasons (spring, $Z=$ 9.17 $\mathrm{y}^{-1}$; summer, $\mathrm{Z}=11.11 \mathrm{y}^{-1}$; autumn, $\mathrm{Z}=11.14$ $\mathrm{y}^{-1}$; winter, $\mathrm{Z}=8.29 \mathrm{y}^{-1}$ ), i.e., the assumption of parallelism of the slopes was met $\left(\mathrm{F}_{\text {season } \mathrm{x} \text { age }}=1.95\right.$ $\left.<\mathrm{F}_{0.05(1), 3,60}=2.75, P=0.13\right)$, while there was heterogeneity in the number of individuals by age among the four seasons $\left(\mathrm{F}_{\text {season }}=18.43>\mathrm{F}_{0.05(1), 3,63}\right.$ $=2.74, P=0$ ), i.e., discounting effects of the covariate (age), season significantly affected the number of animals by age.

\section{DISCUSSION}

There are many factors that can affect the mortality process. Firstly, it may result from episodic events, which induce an increase of mortality (e.g., mortality caused by physical factors). Secondly, mortality may be natural, due to the ageing process, and finally, it may be result from predation, parasitism, and disease (Brey and Gage, 1997). In fact, it can be assumed that most of mortality of populations in the wild is extrinsically determined (e.g., predation) rather than due to the natural ageing process (Kirkwood and Austad, 2000).

An assumption of this study was that mortality estimates would be significantly higher in seasons in which predators of $K$. schubartii had the highest abundance, for instance when juveniles of fish and crustaceans use the estuarine region as nursery grounds. Tanaids are generally reported in the diet of fish and crustaceans that use salt marshes as nursery grounds (Kneib, 1992). It has been suggested that a high mortality of $K$. schubartii is related to predation, as it has been observed the highest densities of $K$. schubartii in sediments from which predators were experimentally excluded (Bemvenuti, 1987).

Although the highest instantaneous rates of total mortality were observed in summer and autumn, these figures were not statistically different than mortality estimates of spring and winter. This result can be emphasized when the instantaneous rate of total mortality is transformed to annual mortality $\left(A=1-e^{-Z}\right)$. In this scenario, differences in annual mortality are extremely small (from the $4^{\text {th }}$ decimal case).

Kalliapseudes schubartii is the predominant prey of the whitemouth croaker fish Micropogonias furnieri (Figueiredo and Vieira, 1998), and of the catfish Netuma barba and Genidens genidens (Araújo, 1984). Among the decapods, the swimming blue crab Callinectes sapidus, the marsh crab Chasmagnathus granulata, and the pink shrimp Farfantepenaeus paulensis prey on $K$. schubartii (Bemvenuti, 1987). Between the end of spring and the beginning of autumn, shallower areas of the estuarine region of the Lagoa dos Patos are used as nursery grounds by juveniles of crustaceans and fish. This would lead to acute predation on the benthic community at these times (Bemvenuti, 1997b).

A high morality rate was also observed in winter. High mortality rate in winter, due to predation, has not been reported for $K$. schubartii. However, circumstantial evidence showed that during winter $K$. schubartii was found in ca. $90 \%$ of the stomach contents of Micropogonias furnieri (Figueiredo and Vieira, 1998). Moreover, during winter $K$. schubartii was the main diet item of Callinectes sapidus in substrates without submersed spermatophytes (like the sampling site of the present investigation) (Asmus, 1989 in Seelinger, 1997).

Nevertheless, mortality rate in winter could also be related with environmental causes, such as a drop in salinity, which is commonly observed in winter in the estuarine region of the Lagoa dos Patos (Garcia, 1997). Kalliapseudes schubartii is a typical species of the mesohaline zone, as this tanaid is rarely found in the oligohaline $(<6)$ zone of the Lagoa dos Patos (Capitoli et al, 1978). Therefore, in winter the effect of low salinity (and maybe the interaction between low salinity and low water temperature) could increase the mortality rate of populations of $K$. schubartii.

To circumvent a high mortality rate, populations of $K$. schubartii should compensate with a high reproductive activity. In the estuarine region of the 
Lagoa dos Patos, the mean size of the onset maturity (L50) of females is attained rapidly (two months after release from the marsupium) (Fonseca and D'Incao, 2003). Moreover, high proportions of brooding females are observed most of year (from spring to early autumn), and these brooding females have up to 47 mancas (juveniles) in the marsupium. Recruitment peaks are observed in spring and summer (Fonseca and D'Incao, 2003), and a small reproductive activity is observed even in winter, which suggests that $K$. schubartii has continuous reproduction. Continuous reproduction of $K$. schubartii has also been suggested elsewhere (Leite et al, 2003).

Altogether, the present investigation showed that the mortality rate of $K$. schubartii was high year round, and it is suggested that this tanaid could be heavily preyed on in all seasons. Intense reproductive activity most of year would be the mechanism to circumvent high mortality rates. Moreover, the assumption of higher mortality of $K$. schubartii in summer/autumn than in spring/winter might not be held in unvegetated soft bottoms of the estuarine region of the Lagoa dos Patos.

\section{ACKNOWLEDGEMENTS}

The National Council for Scientific and Technological Development (CNPq, Brazil) supported this work.

\section{RESUMO}

Kalliapseudes schubartii (Crustacea: Tanaidacea) é um invertebrado tubícola que habita fundos moles de regiões estuarinas e que distribui-se ao longo da costa sudeste e sul do Brasil e na costa uruguaia. Este tanaidaceo é comedor de depósitos e filtrador, e é presa de vários consumidores secundários. Taxas de mortalidade sazonal foram examinadas através de amostras feitas durante um ano num local da região estuarina da Lagoa dos Patos. Os resultados não demonstraram diferenças significativas entre as taxas de mortalidade nas diferentes estações do ano, o que sugere que populações de $K$. schubartii são fortemente predadas ao longo de todo o ano e que a premissa de maior mortalidade no verão/outono pode não ser correta em fundos de águas rasas não vegetados.

\section{REFERENCES}

Araújo, F. J. (1984), Hábitos alimentares de três espécies de bagres marinhos (Ariidae) no estuário da Lagoa dos Patos (RS), Brasil. Atlântica, 7, 47-63.

Bemvenuti, C. E. (1987), Predation effects on a benthic community in estuarine soft sediments. Atlântica, 9, 5-32.

Bemvenuti, C. E. (1997), Benthic invertebrates. In: Seeliger, U.; Odebrecht, C. and Castello, J. P. (Eds.). Subtropical convergence environments: the coast and sea in the southwestern Atlantic. Berlin: SpringerVerlag. pp. 43-46.

Bemvenuti, C. E. (1997b), Unvegetated intertidal flats and subtidal bottoms. In: Seeliger, U.; Odebrecht, C. and Castello, J. P. (Eds.). Subtropical convergence environments: the coast and sea in the southwestern Atlantic. Berlin: Springer-Verlag. pp. 78-82.

Capitoli, R. R.; Bemvenuti, C. E. and Gianuca, N. M. (1978), Estudos de ecologia bentônica na região estuarial da Lagoa dos Patos. 1 - As comunidades bentônicas. Atlantica, 3, 5-22.

Brey, T. and Gage, J. D. (1997), Interaction of growth and mortality in benthic invertebrate populations: empirical evidence for a mortality-growth continuum. Arch. Fish. Mar. Res., 45, 45-59.

Figueiredo, G. M. and Vieira, J. P. (1998), Cronologia alimentar e dieta da corvina, Micropogonias furnieri, no estuário da Lagoa dos Patos, RS, Brasil. Atlântica, 20, 55-72.

Fonseca, D. B. and D'Incao, F. (2003), Growth and reproductive parameters of Kalliapseudes schubartii in the estuarine region of the Lagoa dos Patos (Southern Brazil). J. Mar. Biol. Ass. U.K., 83, 931-935.

Garcia, C. A. E. (1997), Hydrographic characteristics. In: Seeliger, U.; Odebrecht, C. and Castello, J. P. (Eds.). Subtropical convergence environments: the coast and sea in the southwestern Atlantic. Berlin: Springer-Verlag. pp. 18-20.

Highsmith, R. C. (1983), Sex reversal and fighting behaviour: coevolved phenomena in a tanaid crustacean. Ecology, 64, 719-726.

Kirkwood, T .B. L. and Austad, S. N. (2000), Why do we age? Nature, 408, 233-238.

Kneib, R. T. (1992), Population dynamics of the tanaid Hargeria rapax (Crustacea, Peracarida) in a tidal marsh. Mar. Biol., 113, 437-445.

Lana, P. C. and Guiss, C. (1991), Influence of Spartina alterniflora on structure and temporal variability of macrobenthic association in a tidal flat of Paranaguá Bay (Southern Brazil). Mar. Ecol. Prog. Ser., 73, 231-244. 
Leite, F. P. P. (1995), Seasonal and spatial distribution of Kalliapseudes schubartii Mañé-Garzón (Tanaidacea, Crustacea) in the Araçá Region, São Sebastião (SP). Braz. Arch. Biol. Technol., 38, 605-618.

Leite, F. P. P.; Turra, A. and Souza, E. C. F. (2003), Population biology and distribution of the tanaid Kalliapseudes schubarti Mañé-Garzon, 1949, in an intertidal flat in Southeastern Brazil . Braz. J. Biol., 63, 469-479.

Mañé-Garzón, F. (1949), Un nuevo tanaidaceo ciego de sud America, Kalliapseudes schubartii, nov. sp. Conmum. Zool. Mus. Hist. Nat. Montevideo, 3, 1-6.

Muniz, P. and Venturini, N. (2001), Spatial distribution of the macrozoobenthos in the Solis Grande stream estuary (Canelones-Maldonado, Uruguay). Braz. J. Biol., 61, 409-420.

Pauly, D. (1990), Length-converted catch curves and the seasonal growth of fishes. Fishbyte, 8, 33-38.

Rosa-Filho, J. S. and Bemvenuti, C. E. (1998), O sedimento como fator limitante para a distribuição de Kalliapseudes schubartii Mañé-Garzón, 1949 (Crustacea, Tanaidacea) em fundos moles estuarinos. Nauplius, 6, 119-127.

Seelinger, U. (1997), Seagrass meadows. In: Seeliger, U.; Odebrecht, C. and Castello, J. P. (Eds.). Subtropical convergence environments: the coast and sea in the southwestern Atlantic. Berlin: SpringerVerlag. pp. 82-85. 